\title{
Financial Institutions, Financial Contagion, and Financial Crises
}

\author{
Haizhou Huang and Chenggang $\mathrm{Xu}$ \\ CID Working Paper No. 21 \\ July 1999
}

(c) Copyright 1999 Haizhou Huang, Chenggang Xu, and the President and Fellows of Harvard College

\section{Working Papers Center for International Development at Harvard University}




\title{
Financial Institutions, Financial Contagion, and Financial Crises
}

\author{
Haizhou Huang and Chenggang $\mathrm{Xu}^{*}$
}

\begin{abstract}
This paper endogenizes financial contagion and financial crises from financial institutions. We show that financial crises can emanate from financial institutions which generate soft-budget constraints (SBC). The prevailing SBC in an economy distort in-formation such that the interbank lending market faces a "lemon" problem. The lemon problem in the lending market may contribute to bank-run contagions and can lead to the collapse of the lending market while inducing a run on the economy. Moreover, due to the lemon problem in the financial system, a rational government policy in this economy will lead to a SBC trap that all the illiquid banks are to be bailed out. In comparison, we show that an economy with a predominance of diversified financial institutions will be featured by hard-budget constraints. From this point, we show mechanisms that in this economy firms disclose timely information to the banks and to the financial market as a whole. Thus bank runs can be stopped, contagious risks contained and financial crisis prevented.
\end{abstract}

JEL Codes: D2, D8, E58, G2, G3, P5

Keywords: Financial Institutions, Corporate Finance, Bank Run, Financial Contaigion, Financial Crisis

Haizhou Huang is an economist in the Monetary and Exchange Affairs Department of the International Monetary Fund. Email: hhuang@imf.org

Chenggang Xu is a Faculty Research Fellow of CID, a Faculty Associate at HIID, and a lecturer of economics at London School of Economics. Email: c.xu@lse.ac.uk.

\footnotetext{
* We are indebted to Eric Maskin for his important suggestions and advice. We are also grateful to William Alexander, Abhijit Banerjee, Tito Cordella, Charles Goodhart, Nobu Kiyotaki, Janos Kornai, John Moore, Dwight Perkins, Jean-Charles Rochet, and Jean Tirole for helpful comments; to the seminar and conference participants at AEA, EEA, HIID, IMF, LSE, Southampton, and Toulouse; and to Natalie Baumer for editorial assistance.
} 


\title{
FINANCIAL INSTITUTIONS, FINANCIAL CONTAGION, AND FINANCIAL CRISIS
}

\author{
Haizhou Huang and Chenggang Xu
}

\section{INTRODUCTION}

The financial crisis in East Asia presents great challenges to economists. Before the crisis, the East Asian economies had been doing very well - economies had high growth rates, high savings rates, and sound fiscal policies. In addition to exogenous shocks which may have contributed to the overall problem, the question remains whether there are fundamental problems within the respective Asian economies which provide conditions for the crisis?

This paper attempts to analyze the financial institutional problems, to understand how those problems may have resulted in financial crises. Following are some of the more popular explanations for the Asian crisis: the run by panicked investors on the economies, similar to the run by panicked depositors on a bank (Radelet and Sachs, 1998; Stiglitz, 1998); the moral hazard in banking (Krugman, 1998; Akerlof and Romer, 1994); and the collapse of a bubble economy (Edison et al., 1998; Blanchard and Watson, 1982). These arguments are useful to identify potential problems; nevertheless, their arguments may raise many more questions to be studied.

We study generation and transmission mechanism of bank run contagion in financial institutions with unsecured debts. Examples of unsecured debts are banks deposits, noncollateralized or non-insured loans, or loans 'guaranteed' only by reputations which may not be credible when there are grave liquidity shocks. Our theory is complementary to Kiyotaki and Moore (1997) which studies how credit constraints interact with asset prices when debts are secured by collateral assets. They study how that interaction serves as a transmission mechanism through which temporary shocks can generate large and persistent fluctuations in outputs. 
It has been observed that the financial crisis in Asia fundamentally resulted from the inability of their financial institutions to put a halt to loans to "bad" projects ex post. That is the financial institutions provide "soft-budget constraints" (SBC) on firms, similar to what Kornai observed on state enterprises in centralized economies (1980, 1986). We determine from the soft budget syndrome that it affects not only the efficiencies of a financial market, but more important, it distorts the market's information so that the interbank lending market is confronted with a "lemon" problem. The availability of information about bank quality is critical for the operation of the financial market in providing loans to illiquid banks. This lemon problem in the financial market may contribute to bank run contagion that can lead to the collapse of interbank lending markets and induce all investors to panic, thus a run on the economy. ${ }^{1}$

In comparison, an economy with a predominance of diversified financial institutions will be featured by hard-budget constraints (HBC) on firms (with a commitment to stop bad projects ex post). We determine that an HBC economy will disclose timely businessrelated information from the firms to the banks, and to the financial market. Thus in an HBC economy, bank runs can be stopped, contagious risks contained and financial crisis prevented.

In our model there are many banks which receive deposits and invest into projects. Banks rely on interbank lending market to ease liquidity shortage problem when they face liquidity shocks. Although to focus on our main points we do not endogenize the number of banks, having many decentralized banks in the economy is necessary for the following reasons. First, in our theory a decentralized financial system with many banks is a device to solve commitment problem and to reduce contagious risks. Second, competition among banks is important for efficient allocation of financial resources in our model.

To be specific, in our model there are numerous depositors of the type described by Diamond-Dybvig (Diamond and Dybvig, 1983), who are divided into early consumers (who

\footnotetext{
${ }^{1}$ To foucus on our point we donot model peer monitoring in the interbank lending in the sense of Rochet and Tirole (1996). In fact, as long as peer monitoring is much blurred than bank's own monitoring, our basic result will not be changed qualitatively.
} 
consume only at date 1) and late consumers (who consume only at date 3). Ex ante, all depositors are identical in that they don't know their own type until date 1, but they make their deposit decision ex ante. Moreover, there are many entrepreneurs who have innovative ideas, but have to rely on banks to finance their projects. We consider that all projects proposed by entrepreneurs can be either unprofitable ex ante - a bad type; or profitable ex ante - a good type. The type of a project, however, is not known to an entrepreneur until date 1 ; and is not known to the bank(s) until date 2 after the earlier investments are sunk. A bad project will generate no return as it is, but has a potential to generate an ex post profitable return if it is reorganized at date 2 with a right reorganization strategy. But for the involved bank(s) to find a right strategy to reorganize a bad project, they need to posses some particular information.

If a project is co-financed by multiple banks, the asymmetric information and conflict of interest between the banks will make the ex post cost of reorganizing a bad project too high so that a bad project will have to be liquidated. Moreover, such a threat of liquidation will deter entrepreneurs from continuing a bad project after privately learning the true type of a project. That is, multi-bank financing can be used as a commitment device to stop bad projects. We call an economy where all projects are financed by multiple banks as a hard-budget constraint (HBC) economy. In contrast, if a project is financed by one bank, without asymmetric information, there is no commitment device to stop bad projects. An economy where all projects are financed by one bank is a soft-budget constraint (SBC) economy.

In the economy we have constructed, every bank stores the optimal amount of cash to meet expected early consumer withdrawals. The interbank lending market is an instrument for banks to avoid bank runs when some of them face idiosyncratic liquidity shocks - excess early withdrawals. With an HBC economy, all bad projects are stopped at date 1, which is observable by other banks as well. Thus, given the information, when a bank with a good project faces excess early withdrawals, there will be no difficulties for the bank to borrow. Therefore, bank runs happen only to banks which face both technological shocks - those with bad project - and liquidity shocks; solvent banks do not have bank runs when they 
face liquidity shocks. As a result, there is no possibility of having a bank run contagion in an HBC economy.

In an SBC economy, on the other hand, there will be a lemon problem in the interbank lending market. This is because without observable actions were taken against bad projects, such as liquidation, a bank manager may be privy to information concerning a project, which is not available publicly in the marketplace. Thus when a bank is confronted with liquidity shocks and needs to borrow from other banks which do not have all available information concerning the quality of the borrowing banks investment project (asset), potential lenders have to assume the quality of the borrowing banks investment project being average. This will make the cost of borrowing for a better bank be higher. Therefore when a liquidity shock is severe enough, such a high borrowing cost can push a better bank into liquidation. From a bank manager's perspective liquidation is a worse situation than a bank run, because liquidation often implies that management was ineffective, while any bank can experience a bank run. That is, illiquid banks with better asset may face bank run earlier than others. Moreover, a bank run on the better banks will further deteriorate the quality of the lending market and will most likely trigger more earlier withdrawals. In our analysis, we then demonstrate how bank run contagious risks lead to the collapse of the lending market and the spread of depositor panic that all depositors withdraw as of date 1 .

When there is an interbank lending market failure, it may be desirable for the government to step in to provide loans to stop bank run contagions. Due to the lemon problem in an SBC economy, the optimal government policy is to bail out all the illiquid banks indiscriminately. However, when the government's bailout capacity is not sufficient, the best the government can do is to bailout banks randomly. In this case, bank run will occur and contagious risks are very likely to be high, particularly, if contagion has started already, random bailout may be ineffective. The implication is that some aid from outside, like IMF loans, will be necessary so as to restore confidence and financial order to the banking system.

Our theory is closely related to Kornai (1980, 1986), Dewatripont and Maskin (1995), Qian and $\mathrm{Xu}$ (1998) on the institutional problem involving soft budget constraints and project selections; to Diamond and Dybvig (1983) on banking system; and to Akerlof 
(1970) on the lemon problem. Our major contributions to the literature are the following: we endogenize the lemon problem in the interbank lending market and moral hazard problem between firms and financial institutions; we provide a mechanism of panic generation/transmission, bank run contagions, and financial crises. The banking moral hazard problem in our model is consistent with Krugman's intuition of the Asian crisis (Krugman, 1998). Our mechanism gives a theoretical explanation to the observations of Radelet and Sachs (1998), and Stiglitz (1998).

The remainder of the paper is organized as follows. Section 2 briefly discusses the financial institution arrangement in Korea and Taiwan to show the relevance of financial institutions to financial crisis. Section 3 establishes the basic structure of the model. Section 4 analyzes the relationship between financial institutions and soft- and hard-budget constraints, whereas Section 5 investigates how bank run contagions are created under soft-budget constraint and when it can lead to financial crisis. Section 6 examines government policy and endogenize a soft-budget constraint trap, while the final section, Section 7, concludes with some qualifications and elaborations of our theory, a brief literature survey, and further discussions on policy implications of our theory.

\section{FINANCIAL INSTITUTIONS IN KOREA AND TAIWAN}

To illustrate how financial crises may be related to financial institutions, we present brief overviews of the Korean and Taiwan economies. Korea and Taiwan are at similar development stages, and they also have similar technologies, labor inputs, and high savings. However, while Korea is at the center of the East Asian crisis, Taiwan has been much less affected - even though it too has been attacked by international speculators. One possibility to explain this difference may be the substantially different financial institutions in the two economies.

It is well documented that Korean development has been characterized by the establishment of large conglomerates (chaebols) through government-coordinated bank loans; while small- and medium-sized firms financed by dispersed financial institutions have been 
predominant in Taiwan: the market share of the largest 100 firms in Taiwan was approximately 22 percent in the late 1970s and early 1980s, while the comparable share was about 45 percent in Korea (Lee, 1998, p.230).

The Korean government promoted the heavy and chemical industries in the 1970s and promoted specialization in the largest chaebols in the 1980s through both direct and indirect subsidized loans. In the two decades since the early 1970s, more than half of Korean domestic credits were distributed as policy loans with low rates (Stern, Kim, Perkins and Yoo, 1995; Cho and Kim, 1995). Closely related to the subsidies in credits, the lack of financial discipline was so common that there was almost no bankruptcy before 1997 (particularly of chaebols). As a consequence, firms were over-leveraged as their average debt-equity ratio was among the highest in the world beginning in the 1970s (Borensztein and Lee, 1998; Lee, 1998).

In comparison, Taiwan firms relied on much more diversified financial sources. As a consequence, the average debt-equity ratio of all Taiwan firms during the 1985 - 1992 period was about 1.4 and the ratio of large firms was even lower (about 1.2) (Semkow, 1994, p.84).

With a domination of government coordinated bank financing, credits were not allocated efficiently to Korean firms. Using a panel data of 32 Korean manufacturing sectors in the period from 1969 to 1996, Borensztein and Lee (1998) show that credit was allocated preferentially to the sectors with larger firms, with exports, and with worse economic performance. From firm level data for the period 1984 - 86, Dailami and Kim (1994) discovered that subsidized credit encouraged chaebols to hold more financial assets and real estate investments, but not actual productive assets. From a panel data of more than 40,000 manufacturing plants for the period 1983 - 93, Aw, Chung and Roberts (1998) discovered that closing down plant productivity was about the same as the ones in operation. This suggests that decisions involving closing plants were not related to efficiency considerations, i.e. Korea plants did not have financial discipline. Firms in Taiwan, however, were subject to effective financial discipline, with the result that there were frequent bankruptcies in the corporate sector. Inefficient firms were indeed punished: the productivity of closed-down (disciplined) firms was 11.4 percent to 15.5 percent lower than that of the rest firms (Aw 
et al., 1998).

The losses from projects financed by bank loans caused serious problems for Korean banks. At the end of 1986, nonperforming loans at the five largest commercial banks amounted to three times those banks' total net worth (Park and Kim, 1994). To relieve the troubled banks, between 1985 and 1987 the Bank of Korea provided these banks with more than 3 trillion won in subsidized loans (Nam, 1994).

To reform the inefficient loan allocation scheme in the mid-1970s, the Korean government established a credit control system called a "principal transactions" bank system. Under this system, the bank, which was most involved financially with each chaebol, was designated as the principal transactions bank to coordinate all lending activities. Any new credit to be issued by any bank to the chaebol was supposed to be evaluated by the principal bank. However, this principal transactions bank system was ineffective. It was reminiscent of the persistent soft-budget constraint syndrome in centralized economies before and after reforms (Kornai, 1980 and 1986).

As a result of the chronicle soft-budgeting problem in Korean chaebols, before the outbreak of the 1997 crisis the average debt-equity ratio of the 30 top chaebols was about 4.5. Consistently, a recent econometric work shows that a significant part of the total credit in Korea was not used productively (Demetriades and Fattouh, 1998). Some Korean economists claim that the excessive leveraged expansion ultimately resulted in the insolvency of 5 of the top 30 chaebols (Park, 1997) which triggered the financial crisis.

\section{THE MODEL}

In our economy, there are many entrepreneurs, $M$ banks and bank managers, and $N \times M$ depositors.

Entrepreneurs have ideas for new investment projects but no wealth to finance them. In this model any uncertain investment can be a project, such as technological innovation. An entrepreneur can be an inventor or a financier (such as a venture capitalist). Among all the projects proposed by entrepreneurs, $\lambda$ percentage of the projects are the good type, and 
the rest are the bad type. Ex ante, entrepreneurs and banks all do not know which project is good and which is bad, but they are fully aware of the distribution.

A project takes three periods to finish, requires a total investment of $I_{1}+I_{2}+I_{3}$, where $I_{t}$ is the required investment in period $t$, and $I_{t} \gg 1$. The technology of the project has a constant return to scale. A good project generates an ex ante profitable return, $Y>I_{1}+I_{2}+I_{3}$; while a bad project generates no return as it stands. A bad project, however, can be reorganized at date 2 and the best return a reorganized bad project can get is $I_{3}<X<I_{2}+I_{3}$, that is, it is ex ante unprofitable but can be ex post profitable. The expected return of a project in the pool is positive, that is $(1-\lambda) X+\lambda Y-I_{1}-I_{2}-I_{3}>0$.

We assume that if a project is financed, at date 1, an entrepreneur will learn the type of his project, but the bank(s) still will not know of the type. At date 2, the bank(s) will know the type of the project, and if a project is a bad one, a decision should be made either to liquidate or to reorganize.

We assume that an entrepreneur gets a private benefit $b_{t}$ from working on a project, where $t$ denotes the date when the project is either completed or terminated at $t=1,2,3$. Specifically, if the entrepreneur quits the project at date 1 , he gets a low private benefit, $b_{1}>0$. At date 2 , if a bad project is liquidated, the entrepreneur gets an even lower private benefit $b_{2 b}$, where $0 \leq b_{2 b}<b_{1}$. At date 3 , if a bad project is reorganized and completed, it will generate a private benefit $b_{3 b}>b_{1}$ to the entrepreneur; in the case of a good project, it will generates a private benefit, $b_{3 g}>b_{3 b}$, to the entrepreneur. To summarize, we have $b_{3 g}>b_{3 b}>b_{1}>b_{2 b} \geq 0$.

In this economy, bank managers are hired to manage banks, to make investment decisions, and to monitor banks' investments in firms. They are risk neutral and they have incentives for not being identified as bad managers (e.g. career concerns).

All the $M$ banks in the economy are ex ante identical, each has an initial endowment of $Z$, and $N$ depositors each deposit $\$ 1$ in the bank. Thus each bank's assets are $Z+N$. With the $M$ banks, there is an interbank lending market to solve potential liquidity shortage problems. We assume that liquidation of bad project is observable by all the banks.

In our economy there are two types of depositors of the type described by Diamond and 
Dybvig (Diamond and Dybvig, 1983): early and late risk averse consumers, with the early consumers only consuming at $t=1$, and the late consumers only consuming at $t=3$. Ex ante, all depositors are identical and do not become aware of what types they are until $t=1$. Moreover, each of them is endowed with $\$ 1$. They make their investment decision based on the ex ante belief of banking system riskiness, and the market equilibrium return on deposit. Supposedly, they do not have the required expertise to be entrepreneurs or bank managers, nor do they monitor banks because of high surveillance costs.

Each depositor's preference is defined as

$$
U=\pi_{1} u\left(C_{1}\right)+\rho \lambda \pi_{2} u\left(C_{2}\right)
$$

where $C_{j}$ is the consumption of type $j$ depositor; $j=1$ being early consumers who consume at $t=1$ and $j=2$ the late consumers who consume at $t=3 ; \pi_{j}$ is the probability of a depositors being a type 1 or 2 consumers, and $\pi_{1}+\pi_{2}=1 ; \rho<1$ is the discount factor; $\lambda$ is the probability that an investment project is good; $\rho \lambda R>1$, where $R$ is the return from investment; and $u^{\prime}>0, u^{\prime \prime}<0$, and $\left(C u^{\prime}\right)^{\prime}=u^{\prime}+C u^{\prime \prime}<0$.

Now we summarize the timing of the game as follows:

- Date 0: All parties know the distribution of the projects and the depositors, but no one knows the type of each project and the type of each depositor. The bank(s) offer a take-it-or-leave-it contract to the entrepreneur. If the contract is signed, the bank(s) will invest $I_{1}$ units of money into the project during period 1. Depositors make saving decision to a bank.

- Date 1: The entrepreneur learns the type of the project, and may stop the project. In that case the entrepreneur gets a private benefit $b_{1}>0$ and all the banks observe the liquidation of the project. However, unless a project is stopped by the entrepreneur the bank(s) still does (do) not know the type of the project and further $I_{2}$ units of money is invested into the project. Moreover, the bank(s) will know the distribution of their own project better as their private information. Early consumers withdraw money from banks, late consumers make their decisions on withdraw or keeping de- 
posits in banks. A bank facing too many early withdrawals has to borrow, otherwise it has to abort a project resulting in no return.

- Date 2: The type of a project becomes public knowledge:

- If a project is a good type, a further $I_{3}$ will be invested.

- If it is a bad project, a decision on whether to liquidate or to reorganize has to be made.

* If a project is liquidated the bank(s) gets zero and the entrepreneur gets $b_{2 b}<b_{1}$; otherwise,

$*$ if a project is reorganized, $I_{3}$ will be invested.

- After investing $I_{3}$, signals $s_{A}$ and $s_{B}$ are observed by the investor(s) and a reorganization strategy is chosen based on the signals.

- Date 3: All projects are completed,

- for a good project, return $Y$ goes to the bank(s), entrepreneur gets $b_{3 b}>b_{1}$;

- for a bad project, return $X$ goes to the bank(s), entrepreneur gets $b_{3 g}>b_{3 b}$;

- late consumers collect their rewards.

\section{FINANCIAL INSTITUTIONS AND SOFT-BUDGET CONSTRAINTS}

In this section, we demonstrate that if investment decisions are made by one bank there will be intrinsic problems in making commitments to liquidate bad projects, thus leading to soft-budget constraints; while if investment decisions are made by multiple banks, it will help to form commitment devices, thus create hard-budget constraints.

In our model, there are numerous entrepreneurs and $M$ banks in an economy. When an entrepreneur proposes a project to a bank, the bank can either finance the project alone, or can co-finance the project with other banks. We refer to the former as a case of single bank financing, and to the later case as a case of multi-bank co-financing. Here, one 
bank financing reflects the real cases where financing decisions are made by a single agent, such as in the case of government-coordinated financing, where the government makes the decisions, principle bank system where the principle bank makes the decisions (e.g. in South Korea), and of course also a true single-bank financing, or internal financing. Multibank co-financing reflects the cases where there are diversified and decentralized financial institutions and multiple banks/investors are involved in investment decisions.

We model a special case of multi-bank co-financing: two-bank co-financing (the extension from two to many is straightforward). We assume that banks $A$ and $B$ have different specialties in technologies or banking markets.

If a project is a good one, it generates a high return $Y$ no matter whether it is financed by one bank alone or it is co-financed by two banks. That is, from the perspective of the financing decision there is no difference between these two financing methods. Consequently, in the rest of the paper we will focus on the case of bad projects.

Since the return from a completed bad project, $X$, under the best possible reorganization strategy is illustrated by $I_{3}<X<I_{2}+I_{3}$, it is not efficient to undertake a bad project ex ante, but it may be efficient to reorganize it ex post. Therefore, at date 2 a decision has to be made by the bank(s) regarding a bad project: either to reorganize it or to liquidate it.

We assume that there are two strategies $a$ and $b$ to reorganize a bad project during the third period, but only one of them can generate a profit ex post. The right decision of bank(s) in selecting reorganization strategies depends on their information. We suppose that in the case of co-financing, banks $A$ and $B$ will observe different information, represented by signals $s_{A}$ and $s_{B}$ respectively, where $s_{J} \in[\underline{s}, \bar{s}], \underline{s}<\bar{s}$ and $J=A, B$, after $I_{3}$ is invested. ${ }^{2}$

\footnotetext{
${ }^{2}$ There are many possible reasons why banks $A$ and $B$ may have different information ex post if they co-finance, but any bank can have full information ex post if any of them finances a project alone. One possible reason is that observing information $s_{A}$ and $s_{B}$ ex post requires a knowledge of $\bar{s}_{A}$ and $\bar{s}_{B}$ which can only be observed earlier and are essential for the profit of a good project. Given their specialties, bank $A$ can observe $\bar{s}_{A}$ with no costs, but has to pay a cost $c_{A}$ to observe signal $\bar{s}_{B}$; and bank $B$ can observe $\bar{s}_{B}$ with no costs, but has to pay a cost $c_{B}$ to observe signal $\bar{s}_{A}$. Therefore, in the case that banks $A$ and $B$ co-finance a project, they can collect $\bar{s}_{A}$ and $\bar{s}_{B}$ without incurring costs. In the case of single bank financing, bank $J$ will collect signal $\bar{s}_{J}$ and pay cost $c_{J}$ to collect information $\bar{s}_{\bar{J}}$, where $J, \bar{J}=A, B$, and
} 
The following are the basic assumptions regarding how reorganization strategies are related to the information $s_{A}$ and $s_{B}$. We start from efficiency conditions. The first efficiency condition (A-1.1) is that strategy $b$ makes the project ex post profitable if the value of signal $s_{A}$ is higher than the value of $s_{B}$; and strategy $a$ makes the project ex post profitable if the value of signal $s_{A}$ is lower than that of $s_{B}$.

The second efficiency condition (A-1.2) is that the outcome of a wrong strategy is so faulty that the expected net payoff of randomizing between the two strategies is worse than liquidation.

Finally, we make a conflict of interest condition (A-2) that a higher value of $s_{A}$ is more beneficial to bank $A$ if the project is reorganized under strategy $a$ than under strategy $b$; and vise versa. This assumption implies that each bank $J$ has an incentive to use strategy $j$ if their own signal value is higher. ${ }^{3}$

Example 1 Supposedly if a project is to be reorganized at date $2 I_{3}=109$ should be invested. From the table, if $s_{A}$ and $s_{B}$ are 0.6 and 0.4 respectively, it is clear that only strategy $b$ is ex post efficient $(45+65>109)$ thus should be chosen. However, if $s_{A}$ is increased to 0.7, although still only strategy b gives an ex post efficient result, bank $A^{\prime}$ s payoff increases more if strategy a is used. That is, bank $A$ may have an incentive to under report $s_{A}$ to increases the chance that strategy a will be used if she privately observes that $s_{A}$ is moving up.

\begin{tabular}{|l|l|l|l|l|l|}
\hline$s_{A}$ & $s_{B}$ & $V_{A}^{a}$ & $V_{B}^{a}$ & $V_{A}^{b}$ & $V_{B}^{b}$ \\
\hline 0.6 & 0.4 & 40 & 60 & 45 & 65 \\
\hline 0.7 & 0.4 & 48 & 60 & 47 & 65 \\
\hline
\end{tabular}

In the case of multi-bank co-financing, ex post, the two banks have to share their private information as long as they decide to reorganize a bad project. Given the private nature $\overline{J \neq} \bar{J}$. Or, if there are some other reasons, such as an item in the contract, which prevents the two banks from sharing information.

The assumption that $s_{J}$ can only be observed after $I_{3}$ is invested is not essential in the model. Its role is to rule out mixed strategies which will complicate the model without providing more insight (it is rare to observe mixed strategies in financial decisions). Moreover, it is quite realistic.

${ }^{3}$ For the formal expressions of $(\mathrm{A}-1)$ and $(\mathrm{A}-2)$, see the Appendix. 
of the information, and the conflicts of interests between the two banks, if their two banks share the information and the compensation is overly expensive, the information then can be transferred. This is equivalent to saying that bank $B$ will buy the private information $s_{A}$ from bank $A$ when the price that $B$ has to pay, $T\left(s_{A}, s_{B}\right)$, is not too high. It is similar for the bank $A$ buys $s_{B}$ from $B$.

\section{Multi-Bank Co-Financing}

In analyzing the investment decision in multi-bank co-financing, we start with the refinancing decision at date 2 and then consider the entrepreneur's investment decision at date 1. At date 2, when the two banks discover that the project is a bad one, they should decide either to liquidate or to reorganize (i.e., the banks assign a probability of $p$ to refinance the project $^{4}$ ). If they decide to reorganize the project, they will invest $I_{3}$ into the bad project. Then information $s_{A}$ and $s_{B}$ are observed by the two banks respectively and the banks need to decide an optimal reorganization strategy based on what they observed (i.e., the banks assign probabilities of $1-q\left(s_{A}, s_{B}\right)$ and $q\left(s_{A}, s_{B}\right)$ to use reorganization strategy $a$ and $b$ respectively).

In the following we show formally that under conditions (A-1) and (A-2), when a bad project is revealed to the co-investors - the two banks - at date 2, the conflicts between these two banks make it impossible for them to reach an agreement to an efficient reorganization scheme.

Proposition 1 Under conditions (A-1) and (A-2), and under multi-bank co-financing, all bad projects will be liquidated at date 2.

Proof. See the Appendix.

The central message of this proposition is that the informational asymmetry and conflicts of interest between two banks in financing a project can make the costs of reorganizing a project so high that liquidation is always better than reorganization. That is, multi-bank financing can be used as an ex post commitment device to stop bad projects.

\footnotetext{
${ }^{4}$ For example, if their decision is to liquidate the project for sure, they assign $p=0$.
} 
The rationale behind this proposition is the following. Let us look at the case that bank $B$ buys information $s_{A}$ from bank $A$ by paying $T\left(s_{A}, s_{B}\right)$ to $A$ (the case of $A$ buys information $s_{B}$ from $B$ is completely symmetric). That is, an optimal compensation scheme $T\left(s_{A}, s_{B}\right)$ is designed such that $A^{\prime} s$ telling the true value of $s_{A}$ will always make $A$ better off than doing else - the incentive compatibility condition (IC). If we look at the (IC) under the case that the value of $s_{A}$ is higher than $s_{B}$, and the (IC) under the opposite case, and combine them together with the conflict of interest condition (A-2), then we find that under the optimal compensation scheme $T\left(s_{A}, s_{B}\right)$, the incentives of $A$ will lead to a condition that for any given value of $s_{B}$, the higher the value of $s_{A}$, the less likely that strategy $b$ should be used. The efficiency condition (A-1.1), however, implies that for any given value of $s_{B}$, the higher the value of $s_{A}$, the better to use strategy $b$ more often. The only reconciliation between these two conditions is to keep the probability of using strategy $b$ as independent from the signal $s_{A}$, but the efficiency condition (A-1.2) says that this kind of reorganization will make losses ex post, thus it is worse than liquidation. ${ }^{5}$

The commitment of liquidating bad projects by the multi-banks' co-financing has a deterrent effect on entrepreneurs who have bad projects. Afraid of further losses by hiding bad news, an entrepreneur with a bad project will choose to quit once he discovers it is a bad project because the losses incurred by quitting at date 1 are smaller than those at date 2, i.e. $b_{2 b}<b_{1}$. To summarize, we have the following result:

Corollary 1 Under multi-bank financing, entrepreneurs will stop bad projects at date 1 'voluntarily.'

\section{Single-Bank Financing}

We again begin our analysis with the refinancing decision at date 2 and then consider the entrepreneur's investment decision at date 1 . Note that under single bank financing, the

\footnotetext{
${ }^{5}$ For the sake of simplicity, in the proof of this proposition, only the case of two bank's co-financing is analyzed. It is straightforward to extend this to more banks co-financing. Moreover, the more banks involved, the easier to have the conditions of asymmetric information and conflicts of interests being satisfied, thus more likely to have the result.
} 
bank will have all the information $s_{A}$ and $s_{B}$ and will be able to use this information to choose an ex post efficient strategy to reorganize the project such that payoff $X^{*}\left(s_{A}, s_{B}\right)$ is greater than the ex post cost of refinancing, $I_{3}$. Therefore, the bank is not able to commit to terminating a bad project ex post.

Moreover, the fact that the bank cannot commit to terminating a bad project affects the entrepreneur's ex ante incentives to reveal information. When the entrepreneur at date 1 discovers that his project is a bad one, he expects that the project will always be continued and refinanced by the bank at date 2. Consequently, if he decides to quit the project, he gets private benefit $b_{1}$; if he decides to continue the project, the bad project will always be refinanced by the bank and will generate a private benefit $b_{3}>b_{1}$ for the entrepreneur. Therefore, the entrepreneur will always choose to continue a bad project after he privately discovers its type.

Proposition 2 Under assumption (A-1), all single bank-financed bad projects will be reorganized ex post.

An interesting insight from this result reveals that without conflicts of interest and informational asymmetry on the bank side, single-bank financing is not able to solve the asymmetric information problem between the bank and the entrepreneur due to the lack of a commitment to liquidate bad projects. ${ }^{6}$

\section{SOFT-BUDGET CONSTRAINTS AND FINANCIAL CRISES}

\section{Deposit Contract}

We consider a one-good economy. Each depositor's $\$ 1$ endowment can be stored from one period to the next, without any cost, or can be invested in a bank which further invests in a project with stochastic technology, yielding a positive expected return in the future as

\footnotetext{
${ }^{6}$ This result is similar to that of Dewatripont and Maskin (1995). The major difference between their result and ours is that in our model there is no wealth constraint on the bank side; moreover, in the case of multi-bank financing the two banks are involved simultaneously rather than sequentially.
} 
described in the above section. ${ }^{7}$

Similar to Diamond and Dybvig, in our model a market equilibrium in which all agents trade can Pareto dominate that of autarchy; but the market equilibrium does not provide perfect insurance against liquidity shock. The main reason is that complete contingent markets do not exist, because the state of economy (who are the early consumers, who are the late consumers) is not observable ex ante.

At date 0 , consumers make their deposit decision by solving

$$
\begin{aligned}
\max _{K} U & =\pi_{1} u\left(C_{1}\right)+\rho \lambda \pi_{2} u\left(C_{2}\right) \\
\text { s.t. } 1 & =\pi_{1} C_{1}+\pi_{2} C_{2} / R
\end{aligned}
$$

In general, the first order condition of this problem is

$$
u^{\prime}\left(C_{1}^{*}\right)=\rho \lambda R u^{\prime}\left(C_{2}^{*}\right) .
$$

Following Diamond and Dybvig we assume that $C u^{\prime}(C)$ is a decreasing function of $C$ (that is $u^{\prime}+C u^{\prime \prime}<0$ ), thus for $\rho<1$ and $\rho \lambda R>1$, we have

$$
u^{\prime}(1)>\rho u^{\prime}(1)>\rho \lambda R u^{\prime}(R)
$$

Consequently, an ex ante optimal market equilibrium can only be achieved through increasing $C_{1}$ and decreasing $C_{2}$, that is

$$
\begin{aligned}
& C_{1}^{*}>1, \\
& C_{2}^{*}<R .
\end{aligned}
$$

A bank can implement the market solution through a deposit contract (Diamond and Dybvig, 1983). That is for $\$ 1$ deposit at $t=0$, a depositor receives either $C_{1}^{*}$ at $t=1$, or $C_{2}^{*}$ at the end of the exercise. The bank holds $\pi_{1} C_{1}^{*}$ (as cash) at no extra costs, and invests the rest in the illiquid technology which yields a higher return. This ex ante optimal deposit contract is a pure strategy Nash equilibrium. That is, an early consumer always

\footnotetext{
${ }^{7}$ Notice that unlike the Diamond and Dybvig model, which has a positive and deterministic return, in our model, the return is stochastic with an expected positive value.
} 
wants to consume at $t=1$, but a late consumer have no incentive to withdraw early. This

is because as long as $\rho \lambda R>1, u^{\prime}\left(C_{1}^{*}\right)=\rho \lambda R u^{\prime}\left(C_{2}^{*}\right)$ holds if $C_{1}^{*}<C_{2}^{*}$, and any deviation does not pay, as long as other late consumers do not deviate.

However, there may be a bank run equilibrium, that is, a simultaneous deviation of all late consumers. In this case, the bank has to liquidate its project (which has zero value for simplicity) if borrowing from interbank market is not possible or too expensive. As a result, the asset of the bank becomes not enough to meet all the withdrawals. The bank will fail and nothing will be left for late consumers when they withdraw later than others. Anticipating this, all late consumers will withdraw at $t=1$, and the initial belief of bank run is self fulfilling. A key for the existence of a bank run equilibrium is the possibility that a bank cannot solve its liquidity shortage problem by borrowing from interbank market. This turns out to be a key condition to extend Diamond and Dybvig framework from one bank economy to a multi-bank economy.

In our multi-bank economy the total number of depositors is finite with $N$ depositors in each bank, and the realized numbers of type 1 and 2 depositors for each banks are random draws from binomial distributions of $\pi_{1}$ and $\pi_{2}=1-\pi_{1}$ respectively. In the next two subsections, we will analyze equilibrium financial crises in economies with HBC and SBC. We start from the problem faced by bank manager in an HBC economy first.

\section{Equilibrium Financial Crisis in an HBC Economy}

Following our results of an HBC economy, at equilibrium all bad projects are stopped at date 1 and all good projects are completed. Therefore, every bank knows that all continued projects are good ones. The ex ante the expected deposit return in such an economy is:

$$
R^{H}=\frac{\lambda Y-I_{1}-\lambda\left(I_{2}+I_{3}\right)}{I_{1}+\lambda\left(I_{2}+I_{3}\right)}>1 .
$$

To meet expected number of early withdraws a bank's optimal investment decision is to store in cash at the amount of $N \pi_{1} C_{1}^{*}$, and to invest all the rest - at the amount of $N\left(1-\pi_{1} C_{1}^{*}\right)$ - into a project. Every bank co-invests with another bank in one project, 
given the symmetry of the banks, the investment is made in the following way,

$$
N\left(1-\pi_{1} C_{1}^{*}\right)=\frac{1}{2}\left[I_{1}+\lambda\left(I_{2}+I_{3}\right)\right]
$$

In the event that a project is a bad one and aborted at date 1 , the realized value from the investment is zero. ${ }^{8}$ In this case, if there is more than $\pi_{1} N+\frac{Z+\lambda\left(I_{2}+I_{3}\right)}{C_{1}^{*}}$ depositors trying to withdraw at date 1 (think of the depositors who are waiting after the $\left(\pi_{1} N+\frac{Z+\lambda\left(I_{2}+I_{3}\right)}{C_{1}^{*}}\right)$ th one in the withdrawal queue), the bank will run out of cash because of the excessive demand for withdrawals. By knowing that the bank has a bad project and will not be able to pay back it loan, this bank will not be able to borrow in the interbank market. Thus a bank run can occur with a positive probability in an HBC economy, when there are both technological shocks and liquidity shocks. ${ }^{9}$

Now let us look at the case where a bank manager is informed at date 1 that the project turns out to be a good one, which will generate a good positive return at date 3 . In this case, when there is an unexpected excess early withdrawals, the bank can borrow from other banks.

We suppose that other banks in economy also know that this bank has invested in a good project, and will generate a return for sure at

$$
R_{g}^{H}=\frac{Y-I_{1}-I_{2}-I_{3}}{I_{1}+I_{2}+I_{3}}>1 .
$$

In this case, when the bank with a good project faces excess early withdrawals, there will be no difficulties for the bank to borrow from other banks. ${ }^{10}$ Therefore, the bank can solve its liquidity shortage problem by borrowing from other banks so that a bank run is avoided.

\footnotetext{
${ }^{8}$ Notice that even if there are not too many early consumers, a bank run may still occur when late consumers are able to observe liquidation of bad projects. For the sake of simplicity, we do not allow the bank to start another project at date 1. Moreover, this setup avoids giving an HBC economy too greater advantage over an SBC economy, which would divert our focus of the analysis.

${ }^{9}$ The probability that a bank faces both technological shocks and liquidity shocks is $(1-\lambda) \phi^{H}$, where

$$
\phi^{H} \equiv \sum_{j=1}^{\left(1-\pi_{1}\right) N-\frac{Z+\lambda\left(I_{2}+I_{3}\right)}{C_{1}^{*}}} \pi_{1}^{\pi_{1} N+\frac{Z+\lambda\left(I_{2}+I_{3}\right)}{C_{1}^{*}}+j}\left(1-\pi_{1}\right)^{\left(1-\pi_{1}\right) N-\frac{Z+\lambda\left(I_{2}+I_{3}\right)}{C_{1}^{*}}-j} .
$$

${ }^{10}$ The bank can issue a risk-free bond to borrow from other banks. The bond has a price $p$ per share,
} 
Proposition 3 In an $H B C$ economy with symmetric information among bank managers, a bank run happens when a bank faces both technological shocks and liquidity shocks; however, there is no possibility to have a bank run contagion.

The last point of the above proposition is more interesting. An HBC economy will not experience bank run contagion simply because with symmetric information among bank managers, the interbank lending market will be able to provide liquidity to all illiquid banks that are not hit by technological shock. As a result, a bank run does not occur to these banks in an HBC economy.

\section{Equilibrium Financial Crisis in an SBC Economy}

Following our earlier results, in an SBC economy, without commitment of liquidating bad projects at date 2 , entrepreneurs with bad projects will cheat at date 1 . Thus, at date 1 bank managers in an SBC economy do not know the type of the project that they are financing. However, every bank manager will have a better understanding of the risk of their own project. That is, at date 1 , for the manager of the bank $m(m=1, \ldots, M)$, through his monitoring for one period of time, he has a better information than in date 0 , such that he knows that the probability that his project is a good one is $\lambda_{m}$. But this is his private information. We rank the qualities of all the bank as $\lambda_{1}<\lambda_{2}<\lambda_{3}<\ldots<\lambda_{M}$ and denote the average quality as $\bar{\lambda}=\frac{1}{M} \sum_{m=1}^{M} \lambda_{m}$. Therefore, concerning all other banks' projects, the best that a bank manager can determine is their average, $\bar{\lambda}$.

Anticipating the expected withdraw at date 1, a bank's optimal investment decision is to hold $N \pi_{1} C_{1}^{*}$ in cash and invest $N\left(1-\pi_{1} C_{1}^{*}\right)$. Or, the expected investment of a bank is

$$
N\left(1-\pi_{1} C_{1}^{*}\right)=I_{1}+I_{2}+(1-\lambda) I_{3} .
$$

and a value of $\$ 1$ at date 3. $p$ is determined by the competitive bank lending market. In equilibrium $p<1$, otherwise banks would hold all assets in cash. Moreover, as long as $R_{g}^{H} \geq 1 / p$ exists, there is sufficient demand for such a bond. Furthermore, because $C_{1}^{*}<C_{2}^{*}$, it is not worthwhile for any late consumers to withdraw money earlier (at date 1). Thus, the equilibrium is such that all the early consumers withdraw money at date 1 , and all the late consumers wait until date 3 . 
Therefore, if the number of depositors who withdraw at date 1 is no more than the expected number $\pi_{1} N$, the bank will have enough cash to handle the number of withdrawals; however, if the number of early withdrawal is more than $\pi_{1} N$, the bank will have to borrow to meet the depositors demands by issuing bonds. ${ }^{11}$

The bond to be issued by an illiquid bank is a risky one. In the case that a bad project is realized, the bond-issuing bank would not be able to pay anything for the bond. Moreover, due to the asymmetric information among banks, the quality of a bond issued by an illiquid bank is only known to the bank manager himself, but not known by other bank managers. Therefore, the market value of the bond will be different from the private value of the bond, or the value for the bond-issuing bank. Specifically, given that the bank quality is private information of the bond issuing bank, the equilibrium bond market price will be based on the average quality, $\bar{\lambda}$, the bond issued by bank $m$ will have the following structure: for an expected value of $\$ 1$, contingent on the realization of the project at date 3 the bond pays,

$$
\left\{\begin{array}{l}
\frac{1}{\lambda}, \text { if the project is good, } \\
0, \text { otherwise. }
\end{array}\right.
$$

Moreover, the price of the bond is $p^{S}(\bar{\lambda})<1$. Obviously, the lower the $\bar{\lambda}$, the lower the $p^{S}$.

Due to the asymmetric information in the bond market, with different quality of projects, every bond issuing bank faces a different expected cost in issuing a bond. This is because with a higher project quality, a bank expects to pay $\frac{1}{\lambda}$ at a probability of $\lambda_{m}$. That is, if $\lambda_{m}>\bar{\lambda}$, a bank with a $\lambda_{m}$ quality project will pay a cost which is higher than average by

$$
\frac{1}{\bar{\lambda}}-\frac{1}{\lambda_{m}}=\frac{\lambda_{m}-\bar{\lambda}}{\lambda_{m} \bar{\lambda}}
$$

Similarly, if $\lambda_{m}<\bar{\lambda}$, a bank with a $\lambda_{m}$ quality project will have a lower than average cost. Therefore, in such a "lemon" bond market, banks with lower than average quality projects

\footnotetext{
${ }^{11}$ The probability that there is at least $\pi_{1} N+1$ depositors withdrawal at date 1 is:

$$
\phi^{S} \equiv \sum_{j=1}^{\left(1-\pi_{1}\right) N} \pi_{1}^{\pi_{1} N+j}\left(1-\pi_{1}\right)^{\left(1-\pi_{1}\right) N-j}
$$
}


would have more incentive to issue bonds when they face liquidity shocks, while banks with higher than average quality are more reluctant to do so.

At this point, we calculate the expected return of issuing bonds for bank $m$. With the price of $p^{S}$ for each share of the bond, $\frac{n C_{1}^{*}}{p^{S}}$ shares of bonds are needed to raise total $n C_{1}^{*}$ amount of money to pay $n$ excess early withdrawal depositors. Given that the bond pays $\frac{1}{\lambda}$ if the project good which has a probability of $\lambda_{m}$, the expected cost of issuing a bond is $\frac{\lambda_{m}}{\bar{\lambda}} \frac{n C_{1}^{*}}{p^{S}}$. Specifically, the expected net return of bank $m$ by issuing a bond is

$$
\begin{aligned}
E(\mathfrak{R})= & Z+\left(1-\lambda_{m}\right) X+\lambda_{m} Y-I_{1}-I_{2}-\left(1-\lambda_{m}\right) I_{3} \\
& -\left[\left(1-\pi_{1}\right) N-n\right] C_{2}^{*}-\frac{\lambda_{m}}{\bar{\lambda}} \frac{n C_{1}^{*}}{p^{S}} \\
\geq & 0 .
\end{aligned}
$$

Then, given $p^{S}(\bar{\lambda})$ increases in $\bar{\lambda}$, we can easily see that, for any $\lambda_{m}$ there is a $\bar{\lambda}^{*}$ such that

$$
\frac{d}{d n} E(\Re)=n C_{2}^{*}-\frac{\lambda_{m}}{\bar{\lambda}} \frac{C_{1}^{*}}{p^{S}(\bar{\lambda})}=\left\{\begin{array}{l}
>0, \text { if } \bar{\lambda}>\bar{\lambda}^{*} \\
<0, \text { if } \bar{\lambda}<\bar{\lambda}^{*}
\end{array}\right.
$$

It is easy to see that if uncertainty of the projects is low, i.e., $\lambda_{M}-\lambda_{1}$ is small and $\lambda_{M}$ is close to one, then $\frac{\lambda_{m}}{\lambda}$ is close to one for any $\lambda_{m} \in\left[\lambda_{1}, \lambda_{M}\right]$. Thus, the expected return of issuing the bond increases in $n$ and it is always worthwhile to borrow for all illiquid banks. Therefore, a bank run will never happen. However, if the uncertainty of the project is not low in the sense that $\bar{\lambda}$ is substantially lower than $\lambda_{M}$, then there are some banks with $\frac{\lambda_{m}}{\lambda}$ high enough to have their expected returns decrease in $n$. Thus when there are excessive early withdrawals, the expected returns of borrowing will be negative.

From the expected return, we can calculate the cutoff point $\underline{n}$,

$$
\underline{n}\left(\lambda_{m}\right)=\frac{Z+(1-\lambda) X+\lambda Y-I_{1}-I_{2}-(1-\lambda) I_{3}-\left(1-\pi_{1}\right) N C_{2}^{*}}{\frac{\lambda_{m}}{\bar{\lambda}} \frac{C_{1}^{*}}{\widehat{p}^{S}}-C_{2}^{*}} .
$$

When the uncertainty of the projects is not low and the excess number of early withdrawal is larger than the cut off point, $n>\underline{n}\left(\lambda_{m}\right)$, issuing a bond will generate a negative expected return. In this case, borrowing will lead to a later liquidation. However, not borrowing will lead to a bank run. Therefore, a bank manager faces a tough choice. 
It is natural to assume that a bank manager has a strong incentive for not being identified as a poor manager, since he has a career to protect. Moreover, from a bank liquidation one can draw implications that the bank is badly managed. However, if there is a bank run it is hard for one to draw a conclusion about the quality of the management since a well-managed bank may also suffer from a bank run. Therefore, for a manager an expected liquidation at date 3 is worse than a bank run at date 1 . Consequently, when a manager has to choose between an expected liquidation at date 3 and a bank run at date 1 , he will choose the latter. ${ }^{12}$

\section{Proposition 4 In an SBC economy}

1. if the uncertainty of the project pool is low, a bank run never occurs; otherwise,

2. any bank $m$ with a quality $\lambda_{m}>\bar{\lambda}$ and has an excess number of early withdrawal $n>\underline{n}\left(\lambda_{m}\right)$ will suffer from a bank run. ${ }^{13}$

The first result says that for SBC economies with low uncertainty projects, e.g. imitation, a SBC will not cause troubles and there will be no liquidation, no bankruptcy and no bank

\footnotetext{
${ }^{12}$ One may wonder that an ex ante contract based on the public information $\lambda$ can be used to avoid the collapse of the interbank lending market. However, this arrangement is not renegotiation proof, thus it will not help. This is because ex post when every bank has an updated knowledge on $\bar{\lambda}$ about the market and $\lambda_{m}$ about herself, they may have incentives to renegotiate. That is, bank $m$ with $\lambda_{m}>\lambda^{*}$ will choose not to borrow ex post (where $\lambda^{*}$ is the condition agreed upon between the lender and the borrower ex ante) and the lender will like to renegotiate since she fears the default of this borrower. Similarly, an ex ante optimal contract with a scheme to induce a potential borrower to report the true $\lambda_{m}$ will not work either. This is because in our model without assets which can be used as collateral there is a limitation in designing punishment in the incentive scheme; moreover, with the conflict of interest between the lender and the borrower, the cost of inducing the borrower to tell the truth will be too high. A formal proof of this claim can be provided similar our proposition on multi-bank financing leading to a HBC.

${ }^{13}$ Such a bank run happens with a probability $\phi_{m}^{S}$, where

$$
\phi_{m}^{S} \equiv \sum_{j=1}^{\left(1-\pi_{1}\right) N-\underline{n}} \pi_{1}^{\pi_{1} N+\underline{n}+j}\left(1-\pi_{1}\right)^{\left(1-\pi_{1}\right) N-\underline{n}-j}
$$

and $\underline{n}=\underline{n}\left(\lambda_{m}\right)$ is defined in $(3)$.
} 
run. This result sheds some light on the timing of the East Asia financial crisis: it happened when these economies engage higher uncertainty projects.

Following the second result, with some level of liquidity shocks, there will be a bank run contagion which may lead to the collapse of the banking system. This is, because a bank with a better quality project has a higher than average cost in issuing a bond, $\underline{n}$ decreases in $\lambda_{m}$, that is, the higher is the quality (higher $\lambda_{m}$ ), the lower the $\underline{n}$. As a consequence, for a given excess number of early withdrawal $n$, all the better banks with $\underline{n}\left(\lambda_{m}\right)<n$ will pull out of the bond market and suffer from bank runs. When illiquid better banks have bank runs, more late consumers will join the queue of early withdrawals - enlarge liquidity shocks to other banks. Moreover, the bond market is left with weaker banks, which further lead the equilibrium bond price being lowered. With a lower bond price, relatively better banks in the bond market will then be forced out of market. Then, there will be additional bank runs, larger liquidity shocks, and lower bond prices. This process will repeat itself until the bond market prices reach a low enough level that no bank will issue a bond, and late consumers are sufficiently panicked that they all want to withdraw at date 1 . At this point, the entire banking system collapses owing to an economy wide run. The above situation is summarized in the following proposition.

Proposition 5 In an SBC economy if $\bar{\lambda}<\bar{\lambda}^{*}$, excess early withdrawals may cause bank-run contagions which can lead to the collapse of the banking system.

People may wonder how literally should we apply this model to explain reality in the sense that better illiquid banks are subject to run first. In fact, our model can be readily modified to accommodate this by introducing imperfect monitoring from depositors in the sense of Postlewaite and Vives (1987) and Jacklin and Bhattacharya (1988). If the depositors' monitoring is more blurred than the managers' that they divide banks' qualities into groups and are not able to further distinguish them further within each group, then lower quality groups of banks are more likely to suffer liquidity shocks and bank runs. Moreover, the lemon problem induced bank-run contagion mechanism will apply within each group of banks. From there we can show a bank run contagion from worse groups to better groups. 
As a sharp contrast, in an HBC economy whereby information about bank investment quality is revealed to all the bank managers at date 1 because of the liquidation of bad projects, bank runs are always restricted to insolvent banks. Thus, the bond market can never be degenerated, and such a run to the banking system cannot happen!

\section{GOVERNMENT POLICY AND A SBC TRAP}

Given the risks of bank run contagions in an SBC economy, it is conceivable that the government may step in to bail out failing banks in order to reduce bank runs and to stop contagions. Particularly, when there is a bond market failure, it may be desirable for the government to do some thing to stabilize the bond market and stop bank run contagions. However, the problem in an SBC economy is that the government also faces an adverse selection problem: without knowing the type of the projects at date 1 the question remains to determine the optimal government policy in bailing out banks.

In this section, we look at such a policy which minimizes the social welfare losses of bank runs and bailing out banks. We show that in an SBC economy, without changing the financial institution, the best that the government can do is either to rescue all the banks regardless of their qualities, thus creating soft-budget constraints for the banking system which can further lead to an eventual collapse of the economy; or to rescue none of them, thus leaving the banking system vulnerable to contagious risks and financial crisis.

In the economy, the government's role is to be the lender of the last resort in providing low cost loans to the illiquid banks by issuing government loans. ${ }^{14}$ The government, however, has no information to distinguish good banks from bad ones. We suppose that the government issues a bond to an illiquid bank such that the bond lends a price of $p^{G}$ to the bank and the bank pays back the bond at date 3

$$
\left\{\begin{array}{l}
\frac{1}{\lambda_{G}}, \text { when the project is good, and } \\
0, \text { when the project is bad. }
\end{array}\right.
$$

\footnotetext{
${ }^{14}$ See Goodhart and Huang (1998) for a model of the lender of last resort and more discussions on issues related to lender of last resort.
} 
The government chooses $\lambda_{G}$ to lend low cost loans to an illiquid bank $m$ such that its expected payback is cheaper than what it is borrowing, that is,

$$
\frac{1}{\lambda_{G}}<\frac{1}{\lambda_{m}}
$$

The cost that issuing this government bond to illiquid banks is,

$$
\frac{1}{\lambda_{m}}-\frac{1}{\lambda_{G}}=\frac{\lambda_{G}-\lambda_{m}}{\lambda_{G} \lambda_{m}}>0
$$

for all banks with $\lambda_{m}<\lambda_{G}$.

The cost of liquidating a project because of a bank run at date 1 (given that $I_{1}$ is sunk cost at date 1 , the cost of liquidating a project will exclude it) is:

$$
\left(1-\lambda_{m}\right) X+\lambda_{m} Y-I_{2}-\left(1-\lambda_{m}\right) I_{3}>0
$$

The expected return of bank $m$ in buying the government loan is

$$
\begin{aligned}
E(\mathfrak{R})= & Z+\left(1-\lambda_{m}\right) X+\lambda_{m} Y-I_{1}-I_{2}-\left(1-\lambda_{m}\right) I_{3} \\
& -\left[\left(1-\pi_{1}\right) N-n\right] C_{2}^{*}-\frac{\lambda_{m}}{\lambda_{G}} \frac{n C_{1}^{*}}{p^{G}} \\
\geq & 0 .
\end{aligned}
$$

For any given excess number of early withdrawals $n$, from the expected return, we can calculate a cutoff point $\lambda_{\bar{m}}$ such that when the quality of a bank $m$ is higher than the bank $\bar{m}$, or $\lambda_{m}>\lambda_{\bar{m}}$, buying a government bond (receiving a government loan) will generate a negative expected return for bank $m$.

$$
\lambda_{\bar{m}}=\frac{p^{G} \lambda_{G}\left\{Z+X-I_{1}-I_{2}-I_{3}+\left[n-\left(1-\pi_{1}\right) N\right] C_{2}^{*}\right\}}{n C_{1}^{*}-\left(Y-X+I_{3}\right) p^{G} \lambda_{G}} .
$$

Supposedly, now there are $\mathfrak{m}$ banks (this number is not very small) in the economy all having $n$ excess early withdrawals and the quality of these $\mathfrak{m}$ banks are sorted as $\lambda_{1}<\lambda_{2}<$ $\ldots<\lambda_{\mathfrak{m}}$. Due to the lemon problem in the bond market, without the assistance of the government, these illiquid banks may all have bank runs, which may in all possibility result in panic of more late depositors who will decide to withdraw as well. Then there will be 
more bank runs, which will trigger additional panic. Finally, this deteriorating situation will lead to run to the economy.

If the government decides to bail out some of the illiquid banks by issuing bonds, then for the given $n$ there exists an $\bar{m}$ such that all $\bar{m}$ illiquid banks will have a non-negative return in buying the government bond; but all other $\mathfrak{m}-\bar{m}$ illiquid banks will have a negative expected return in buying the government bond. That is, if the scheme is designed that $\lambda_{G}=\lambda_{\bar{m}}$, all the illiquid banks that are in a better financial position than $\bar{m}$ will not chose to be rescued by the government scheme and will experience bank run; and all the weaker banks will be rescued by the government scheme. However, the $\mathfrak{m}-\bar{m}$ more healthy banks's being run by depositors may trigger a panic among late consumption depositors who will make runs on the other banks as well. Without any additional government intervention, this may result in the run on all the other banks in the economy as well, so that all the banks in the set $\mathfrak{M} \backslash \mathfrak{N}$ will be subject to bank runs, where $\mathfrak{M}$ signifies the set of all the banks in the economy; and $\mathfrak{N}$ denotes the set of the banks which are bailed out through the government bond scheme.

For the sake of simplicity, we suppose that the government is able to issue bonds only once, and all the banks in the economy, which are not bailed out by the government, will be subject to bank runs. ${ }^{15}$ Then the expected costs of bailing out the $\bar{m}$ banks in the set $\mathfrak{N}$ is

$$
E\left(\mathfrak{C}_{\mathfrak{N}}\right)=\sum_{m \in \mathfrak{N}} \frac{\lambda_{G}-\lambda_{m}}{\lambda_{G} \lambda_{m}} \frac{n_{m} C_{1}^{*}}{p^{G}} .
$$

Notice that $E\left(\mathfrak{C}_{\mathfrak{N}}\right)$ is decreasing with $\lambda_{m}$. That is, the lower the quality of a bank $(\lambda$ decreases), the higher the costs are of saving it. Moreover, the expected costs of letting all the other banks (in the set $\mathfrak{M} \backslash \mathfrak{N}$ ) experience runs is

$$
E\left(\mathfrak{C}_{\mathfrak{N}^{\prime}}\right)=\sum_{m \in \mathfrak{M} \backslash \mathfrak{N}}\left[\left(1-\lambda_{m}\right) X+\lambda_{m} Y-I_{2}-\left(1-\lambda_{m}\right) I_{3}\right]
$$

Notice that $E\left(\mathfrak{C}_{\mathfrak{N}^{\prime}}\right)$ is an increasing function of $\lambda_{m}$. That is, the higher the quality of

\footnotetext{
${ }^{15}$ Here we assume that as long as the number of illiquid banks which are not being bailed out is large, their bank runs will trigger an economy wide bank run. We plan to analyze this condition, as well as the dynamics of government policy and bank run, in our future research.
} 
bank ( $\lambda$ increases), the higher the cost is of a bank run. We suppose that the government's objective is to design a bailing out scheme by issuing a government bond to minimize the expected total costs, $E(\mathfrak{C})$, which include the expected costs of bailing out the $\bar{m}$ banks and the expected costs of letting all the other banks to be run. Obviously the expected social costs are:

$$
E(\mathfrak{c})=E\left(\mathfrak{C}_{\mathfrak{N}}\right)+E\left(\mathfrak{C}_{\mathfrak{N}^{\prime}}\right)
$$

Even without looking at a model, one can determine that it is desirable to select a government bailing out strategy to halt bank runs at minimum social costs. However, given that the government does not know each bank's risk profile, it faces a "lemon" problem, even though the government bond market will not collapse, since it is supported by a social welfare maximizing government. With this lemon problem, as we shown above, for any given bond price $p^{G}$ and pay schedule $\frac{1}{\lambda_{G}}$, only weaker banks with $\lambda<\lambda_{G}$ would benefit from the government subsidy and thus be willing to request government assistance. Meanwhile, all the stronger banks with $\lambda>\lambda_{G}$ would be penalized by the government bailing-out scheme, and thus would not be willing to ask for government assistance. ${ }^{16}$ As a result, for any selective bail out scheme $\lambda_{G}$, where $\lambda_{1}<\lambda_{G}<\lambda_{M}$, all the stronger banks will suffer bank runs while all the weaker banks will be bailed out. Therefore the social costs of selectively bailing out is higher than bailing out all the illiquid banks. We record this outcome in the following proposition.

Proposition 6 As long as the financial institution is not changed to harden budget constraints, a rational government policy an SBC economy will lead the economy into a softbudget constraint trap that all the illiquid banks are bailed out by the government indiscriminately.

\footnotetext{
${ }^{16}$ Recall that the ranking of the qualities of all the banks in the economy is as follows, $\lambda_{1}<\lambda_{2}<\lambda_{3}<$ $\ldots<\lambda_{M}$. Morover, $E\left(\mathfrak{C}_{\mathfrak{N}^{\prime}}\right)$ is an increasing function of $\lambda_{m}$ and $E\left(\mathfrak{C}_{\mathfrak{N}}\right)$ is a decreasing function of $\lambda_{m}$. That is, the best quality bank, the one with a quality $\lambda_{M}$, has the highest bank run cost and the lowest bailing out cost among all the banks; and the lowest quality bank, the one with a quality $\lambda_{1}$, has the lowest bank run cost but the highest bailing out cost among all the banks.
} 
The fundamental reason for such a SBC trap is the commitment problem of banks in an economy which generates lemon problems in the banking system. Moreover, this proposition presents an important result that the soft-budget syndrome of government policy is generated from commitment problems of banks failing to stop bad projects. The government's soft-budget policy will induce more moral hazard problem from bank managers, as has been argued by Kornai and Krugman. In the end, the economy becomes a victim of this soft budget constraint trap.

A scheme which induces stronger banks to seek government assistance while leaving weaker banks to deal with bank runs is one that would require the government to reverse its bond payment scheme such that a borrower should pay more in a deteriorating state than that one in a good state. However, such a policy is not feasible as long as a failed bank has a limited liability when it faces a run or goes bankrupt. Perhaps that is why in reality we never see this kind of government policy in operation in dealing with varies banking crises, such as in policies related to deposit insurance and the discount window.

In the above analysis the government has unlimited resources to bail out all the troubled banks, thus bank run can be completely prevented. However, when the number of illiquid banks is large and the government has a binding budget constraint in dealing with them, then the government will not be able to bail out all the banks. Given the lemon problem in the banking system, the best the government can do is to bail out banks randomly. In this case, bank runs may occur and contagious risks cannot be eliminated. This is because without knowing banks' quality and which bank will be bailed out by the government, late consumers face uncertainties of losing their deposits. Thus, the following occurs:

Corollary 2 In an SBC economy, if the government does not have enough capacity to bail out all the illiquid banks, the best the government can do is to bail out banks randomly; as a result, all the banks which do not receive government assistance are run by the depositors.

In contrast, in an HBC economy, both the market and the government are aware of the quality of illiquid banks. Thus if there is a need for the government to intervene, for instance, if there is an unexpected magnitude of liquidity shocks, the government would be 
able to bail out only the solvent illiquid banks. Therefore, in addition to a higher efficiency in a government rescue plan, the burden of the government's plan is much less because insolvent banks can be identified and do not need to be bailed out.

Corollary 3 In an HBC economy, if the interbank bond markets do not function, the government bails out only solvent illiquid banks. Consequently, contagious risks are much smaller than in an SBC economy.

\section{CONCLUDING REMARKS}

This paper endogenizes contagious risks and financial crises from financial institutions. We began with our analysis from deriving soft- (and hard-) budget constraints from different financial institutions. Then we showed how a soft-budget constraint generates information asymmetry among banks about their solvency, a factor which inevitably leads to a "lemon" problem in the interbank lending market. The lemon problem in the interbank lending market impedes particularly strong banks from securing loans to solve liquidity shortage problems when they face liquidity shocks. Thus bank runs may break out, which further worsens the lemon problem and can lead to a collapse of the entire banking system. In contrast, under hard-budget constraints timely information of bank quality is disclosed relative to the whole banking system. This makes interbank lending markets function well in providing loans to illiquid but solvent banks. Thus solvent banks will be rescued and financial crisis prevented.

Our theory sheds some light on reconciling the seemingly paradoxical phenomena of the 'East Asian Miracle' in the three decades prior to 1997 compared to the 'East Asian Financial Crisis' in the period after 1997. In the period of early development, that is the catching up period of 1960s to the early 1990s, the uncertainty of the projects are low due to the nature of technological imitation. In this case, our theory predicts that the efficiency of an SBC economy is not lower than an HBC one; moreover, there is no liquidation of projects and bank runs are nonexistent. That is, an SBC economy appears even outperforming an HBC economy, and it may attract a number of investments. However, if for some reason the 
uncertainty of the projects rises precipitously, for example, when an economy is already on the technological frontier thus have to try its own innovation (e.g. South Korea since early 1990s), the negative effects of an SBC economy will dominate and finally lead to troubles in its financial system.

Some remarks on our theory are in order. First, within our framework it can be shown easily that contagious risk will be greatly reduced if there is only one bank although there will be some efficiency loss due to the lack of competition. This simple analysis captures some feature on reform/liberalization of banking systems. For instance, a major reform measure in the transitions from centralized economies into market economies is to change the banking system from a literally one bank system (at least conceptually one can regard all the state banks as branches of the one state bank) into a multi-bank system. Many of the banking system liberalization processes share this spirit as well. According to our theory, a banking system reform designed to enhance competition as described above can induce huge contagious risks to the system if the system is not designed to harden budget constraints at the same time.

Second, our theory is not designed specially for the East Asian financial crisis. Instead, it is a very basic model to help one's general understanding of financial crises. In the real world, there may not exist a simple HBC economy such that all the bad projects are liquidated as cleanly and early as we modelled. That is, even in a well-developed market economy there exists some SBC financial and economic institutions which may cause bank runs or even financial crises, but at a lessen degree than in an economy which is predominated by SBC. However, the basic message of our theory is clear.

Third, in this paper, to study financial crises from a purely economic view we provide an institutional foundation of soft-budget constraints where no political problem appears and every agent maximizes his economic gain. However, this does not imply that our theory of financial crises cannot be applied to other institutions. In fact, our theory of financial crises is general enough that any institutional foundation of an SBC economy (e.g. a foundation based on political considerations, Segal, 1998) applies and can get the same qualitative results. 
In the following we compare some of the literature with our work. Allen and Gale (1998) in the Diamond and Dybvig one-bank framework shows that bank runs are related to business cycle, rather than as results of simple "sunspots". We are in agreement with their view in that fundamentals affect financial crises, and we argued that financial institutions are such a fundamental factor, especially in a multi-bank banking system. Chang and Velasco (1998) extends the Diamond and Dybvig model into an open economy model. They show that the illiquidity of the domestic financial system is at the center of the financial crisis in emerging markets. We regard the Chang and Velasco model to be complementary to our own theory. In fact, we can readily apply their approach to extend our model and explain how domestic financial institutions interact with international financial issues and how an over-borrowing syndrome in the sense of McKinnon and Pill (1997) is generated. Edison et al (1998) study how a major exogenous shock, such as the burst of an asset bubble or a currency shock (a sudden devaluation) can lead to financial collapse. As a comparison, in our model, there is no exogenous bubble produced, although the collapse of the financial system in our economy may make people feel like a bubble has burst. Chan-Lau and Chen (1998) argues that when banks stop monitoring their lending properly, small changes in the economic outlook can produce large fluctuations. In our model, however, banks are constantly monitoring their investments regardless of booming or crushing, but monitoring itself may not be able to get all the information needed, and we have thus argued that a proper institution is required. Avery and Zemsky (1998), Calvo and Mendoza (1995), and Chari and Kehoe (1996) all study volatility of financial markets as herding behavior of investors, which has a theoretical foundation by Banerjee (1992) and Bikhchandani et al (1992). Rigobon (1998) studies investors' overreaction as the result of a learning problem, where the informational content of signals changes through the business cycles.

From our theory, we derive that an optimal government policy to prevent a financial crisis in an SBC economy is to bailout all the illiquid banks. This can be explained by the softbudget syndrome of government policy with respect to the banking system, which is rooted in financial institutions. Another immediate important policy implication of our theory on financial system reform and on financial-crisis-prevention policy is that transparency of the 
banking system is critical. However, transparency cannot be achieved alone by imposing government regulation; instead, it can only be achieved by reforming the financial institution to tighten budget constraints at the micro level.

Moreover, our theory has implications to many policy solutions proposed in the literature. In the following we give a brief summary of our implications to Dewatripont-Tirole (Dewatripont and Tirole, 1994) policies (DT policy for short) in dealing with failure of banks. The first set of DT policies are: 1) to liquidate illiquid banks; 2) to allow solvent and liquid banks to take over illiquid banks; and 3) to provide loans to illiquid banks. Our theory demonstrates that in an HBC economy, with sufficient information on the solvency of the illiquid banks, the government should consider the trade-off between closing down illiquid banks and letting solvent liquid banks take over illiquid banks; or to provide loans to solvent illiquid banks. However, in an SBC economy, without the information of the solvency of the banks, the government has no other choice but to provide loans to all the illiquid banks or to provide loans to a proportion of them randomly. With respect to nationalizing illiquid banks, our theory implies that it may work as an emergency measure if nationalization has an informational value that with the control right the government may be able to identify solvent banks. However, it will probably not work in long run because a nationalized bank will likely induce an SBC environment. 


\section{REFERENCES}

[1] Akerlof, George A. (1970), "The Market for Lemons: Quality Uncertainty and the Market Mechanism," Quarterly Journal of Economics, 89: 488-500.

[2] Akerlof, George A., and Paul M. Romer (1993), "Looting: The Economic Underworld of Bankruptcy for Profit." Brookings Papers in Economic Activity 2, 1-60.

[3] Allen, Franklin, and Douglas Gale (1998), "Optimal Financial Crises", Journal of Finance, $53(4), 1245-1284$.

[4] Avery, Christorpher, and Peter Zemsky (1998), "Multidimensional Uncertainty and Heard Behavior in Financial Markets," American Economic Review, 88(4): 724-748.

[5] Aw, Bee Yan, Sukkyun Chung, and Mark J. Roberts (1998), "Productivity and Turnover in the export Market: Micro Evidence from Taiwan and South Korea," NBER Working Paper, forthcoming.

[6] Banerjee, Abhijit (1992), "A Simple Model of Herd Behavior," The Quarterly Journal of Economics, 107, Aug. 1992.

[7] Bikhchandani, S., David Hirshleifer, and I. Welch (1992), "A Theory of Fads, Fashion, Custom, and Cultural Changes as Informational Cascades," Journal of Political Economy, 100(51), 1992.

[8] Blanchard, Oliver, and Mark Watson (1982), "Bubbles, Rational Expectations, and Financial Markets," in Paul Wachtel (ed.), Crisis in the Economic and Financial Structure. Lexington, MA: Lexington Books, 1982.

[9] Borensztein, Eduardo, and Jong-Wha Lee (1998), "Financial Distortions and Crisis in Korea," mimeo, IMF and Korea University, 1998.

[10] Calvo, G., and E. Mendoza (1995), "Reflections on Mexico's Balance of Payments Crisis: A Choronicle of a Death Foretold," mimeo, University of Maryland. 
[11] Chan-Lau, Jorge A. and Zhaohui Chen (1998), "Financial crisis and credit crunch as a result of inefficient financial intermediation - with reference to the Asian financial crisis," IMF Working Paper WP/98/127, Washington, International Monetary Fund.

[12] Chang, Roberto and Andres Velasco (1998), "Financial Crises in Emerging Markets: A Canonical Model," Federal Reserve Bank of Atlanta Working Paper 98-10.

[13] Chari, V.V. and P. Kehoe (1996), "A Self-Fulfilling Model of Mexico's 1994-95 Debt Crisis," mimeo, Federal Reserve Bank of Minneapolis.

[14] Cho, Yoon Je, and Joon-Kyung Kim (1995), "Credit Policies and the Industrialization of Korea," Discussion Paper 286, The World Bank, 1995.

[15] Demetriades, Panicos and Bassam Fattouh (1998), "Unproductive Credit' and the South Korean Crisis," mimeo, South Bank University.

[16] Dewatripont, Mathias, and Eric Maskin (1995), "Credit and Efficiency in Centralized and Decentralized Economies," Review of Economic Studies, 1995.

[17] Dewatripont, Mathias, and Jean Tirole (1994), The Prudential Regulation of Banks, Cambridge (Mass.): MIT Press.

[18] Diamond, Douglas (1984), "Financial Intermediation and Delegated Monitoring," Review of Economic Studies, 51(July): 393-414.

[19] Diamond, Douglas, and Phillip Dybvig (1983), "Bank Runs, Liquidity, and Deposit Insurance," Journal of Political Economy, 91:401-419, 1983.

[20] Edison, Hali J., Pongsak Luangaram and Marcus Miller (1998), "Asset Bubbles, Domino Effects and 'Lifeboats': Elements of the East Asian Crisis," CEPR Discussion Paper Series 1866, 1998.

[21] Goodhart, Charles A.E., and Haizhou Huang (1998), "A Model of the Lender of Last Resort," FMG Discussion Paper 313, London School of Economics, 1999. 
[22] Huang, Haizhou, and Chenggang Xu (1998), "Financing Mechanisms and R\&D Investment," FMG Discussion Paper, London School of Economics, forthcoming.

[23] Jacklin, Charles J. and Sudipto Bhattacharya (1988), "Distinguishing Panics and Information-based Bank Runs: Welfare and Policy Implications," The Journal of Political Economy, 96(3): 568-592.

[24] Kyotaki, Nobuhiro and John Moore (1997), "Credit Cycles," Journal of Political Economy, 105: 211-248, 1997.

[25] Kornai, Janos (1980), Economics of Shortage. Amsterdam: North-Holland, 1980.

[26] Kornai, Janos (1986), "The Hungarian Reform Process: Visions, Hopes, and Reality," Journal of Economic Literature, 24 (4), December 1986.

[27] Krugman, Paul (1998), "What Happened to Asia?" mimeo, MIT, 1998.

[28] Lee, Kyu Uck (1998), Competition Policy, Deregulation and Economic Development. Seoul: KIET,1998.

[29] McKinnon, Ronald, and H. Pill (1997), "Creditable Economic Liberalizations and Overborrowing," American Economic Review Papers and Proceedings, 87(2): 189-193.

[30] Nam, Sang-Woo (1994), "Korea's Financial Reform Since Early 1980s," in Gerald Caprio, Jr., Izak Atiyas, and James A Hansen (eds.), Financial Reform: Theory and Experience. Cambridge: Cambridge University Press, 1994.

[31] Park, Kyong-So (1997), "Chaebol Leveraged Management: Current Status and Reform Plans," mimeo, Korea Institute of Finance, September 1997.

[32] Park, Yung Chul, and Dong-Won Kim (1994), "Korea: Development and Structural Change of the Banking System," in Hugh T. Patrick and Yung Chul Park (eds.), The Financial Development of Japan, Korea, and Taiwan: Growth, Repression, and Liberalization. Oxford: Oxford University Press, 1994. 
[33] Postlewaite, Andrew and Xavier Vives (1987), "Bank Runs as an Equilibrium Phenomenon, " The Journal of Political Economy, 95(3): 485-491.

[34] Qian, Yingyi, and Chenggang Xu (1998), "Innovation and Bureaucracy Under Soft and Hard Budget Constraints," Review of Economic Studies, 66(1), 1998.

[35] Radelet, Steven, and Jeffrey Sachs (1998), "The East Asian Financial Crisis: Diagnosis, Remedies, Prospects," mimeo, Harvard University, 1998.

[36] Rigobon, Roberto (1998), "Informational Speculative Attacks: Good News is No News," mimeo, Sloan School of Management, MIT.

[37] Rochet, Jean-Charles, and Jean Tirole (1996), "Interbank Lending and Systemic Risk," Journal of Money, Credit, and Banking, 28(4): 733-762.

[38] Segal, Ilya (1998), "Monopoly and Soft Budget Constraint," Rand Journal of Economics, 29(3): 596-609.

[39] Semkow, Brian Wallace, Taiwan's Capital Market Reform - The Financial and Legal Issues. Oxford: Clarendon Press, 1994.

[40] Stern, Joseph J., Ji-hong Kim, Dwight H. Perkins, and Jung-ho Yoo (1995), Industrialization and the State: The Korean Heavy and Chemical Industry Drive, HIID and KDI, 1995.

[41] Stiglitz, Joseph (1998), "Sound Finance and Sustainable Development in Asia," Keynote Address to the Asia Development Forum, The World Bank, 1998. 


\section{Appendix}

The formal expression of the efficiency assumptions are the following. Assumption A-1.1:

$$
\left\{\begin{array}{l}
X^{b}\left(s_{A}, s_{B}\right)-I_{3}>0>X^{a}\left(s_{A}, s_{B}\right)-I_{3}, \text { when } s_{A}>s_{B} ; \\
X^{b}\left(s_{A}, s_{B}\right)-I_{3}=X^{a}\left(s_{A}, s_{B}\right)-I_{3}=0, \text { when } s_{A}=s_{B} ; \\
X^{a}\left(s_{A}, s_{B}\right)-I_{3}>0>X^{b}\left(s_{A}, s_{B}\right)-I_{3}, \text { when } s_{A}<s_{B} .
\end{array}\right.
$$

where $X^{j}\left(s_{A}, s_{B}\right)$ is the total payoff of the reorganized project enjoyed by the bank(s) when strategy $j$ is in action. In the case of co-financing, we denote the payoff under strategy $j$ to bank $J$ by $X_{J}^{j}\left(s_{A}, s_{B}\right)$, where $j=a$ or $b$ and $J=A$ or $B$. Thus, $X^{j}\left(s_{A}, s_{B}\right)=$ $V_{A}^{j}\left(s_{A}, s_{B}\right)+V_{B}^{j}\left(s_{A}, s_{B}\right) \cdot{ }^{17}$

Assumption A-1.2:

$$
q X^{b}\left(s_{A}, s_{B}\right)+(1-q) X^{a}\left(s_{A}, s_{B}\right)-I_{3}<0
$$

where $q=\operatorname{Pr}\left(s_{A}>s_{B}\right){ }^{18}$

Conflict interest assumption A-2: for any $s^{h}>s^{l}$,

$$
\begin{aligned}
& V_{A}^{a}\left(s_{A}^{h}, s_{B}\right)-V_{A}^{a}\left(s_{A}^{l}, s_{B}\right)>V_{A}^{b}\left(s_{A}^{h}, s_{B}\right)-V_{A}^{b}\left(s_{A}^{l}, s_{B}\right)>0, \\
& V_{B}^{b}\left(s_{A}, s_{B}^{h}\right)-V_{B}^{b}\left(s_{A}, s_{B}^{l}\right)>V_{B}^{a}\left(s_{A}, s_{B}^{h}\right)-V_{B}^{a}\left(s_{A}, s_{B}^{l}\right)>0 .
\end{aligned}
$$

\section{Proof of Proposition $4.1^{19}$}

We show that if each bank $J$ is able to observe only $s_{J}(J=A$ or $B)$ after $I_{3}$ is invested, under $(\mathrm{A}-1)$ and $(\mathrm{A}-2)$ there is no efficient incentive compatible scheme $q\left(s_{A}, s_{B}\right)$ and $T\left(s_{A}, s_{B}\right)$ which can induce bank $J$ to tell the true value of $s_{J}$; thus there is no efficient scheme to reorganize the project. As a result, the banks choose to liquidate the bad project.

In the following proof, we first analyze bank $A$ 's incentive problem. For this purpose, we fix $s_{B}$ at an arbitrary value $s^{*} \in(0,1)$.

\footnotetext{
${ }^{17}$ If we relaxe assumption (A-1.1) such that if signal $s_{A}$ is higher than $s_{B}$, strategy $b$ always makes the project more profitable ex post than strategy $a$ and some times only strategy $b$ makes the project profitable ex post; and vice versa, our results will not be changed qualitatively.

${ }^{18}$ Any randomization based on $\widetilde{q} \in[0,1]$ and $\widetilde{q} \neq q$ cannot get a better result than (A-1.2).

${ }^{19}$ The proof of this proposition is influenced by Maskin (1992) which shows that an information asy mmetry between two parties can make auctions inefficient.
} 
Given compensation scheme $T\left(s_{A}, s_{B}\right)$ and strategy $q\left(s_{A}, s_{B}\right)$, bank $A$ should tell the truth only if the expected payoff of doing so is not worse than false reporting. That is, the incentive compatibility (IC) condition is:

$$
\begin{aligned}
& q\left(s_{A}, s_{B}\right) V_{A}^{b}\left(s_{A}, s_{B}\right)+\left(1-q\left(s_{A}, s_{B}\right)\right) V_{A}^{a}\left(s_{A}, s_{B}\right)+T\left(s_{A}, s_{B}\right) \\
\geq & q\left(\widehat{s}_{A}, s_{B}\right) V_{A}^{b}\left(s_{A}, s_{B}\right)+\left(1-q\left(\widehat{s}_{A}, s_{B}\right)\right) V_{A}^{a}\left(s_{A}, s_{B}\right)+T\left(\widehat{s}_{A}, s_{B}\right),
\end{aligned}
$$

where $\widehat{s}_{A}$ is the false report of the signal.

In the case that the information $s_{A}=s_{A}^{h}>s^{*}$, the IC is

$$
\begin{aligned}
& q\left(s_{A}^{h}, s_{B}\right) V_{A}^{b}\left(s_{A}^{h}, s_{B}\right)+\left(1-q\left(s_{A}^{h}, s_{B}\right)\right) V_{A}^{a}\left(s_{A}^{h}, s_{B}\right)+T\left(s_{A}^{h}, s_{B}\right) \\
\geq & q\left(s_{A}^{l}, s_{B}\right) V_{A}^{b}\left(s_{A}^{h}, s_{B}\right)+\left(1-q\left(s_{A}^{l}, s_{B}\right)\right) V_{A}^{a}\left(s_{A}^{h}, s_{B}\right)+T\left(s_{A}^{l}, s_{B}\right),
\end{aligned}
$$

that is,

$$
\begin{aligned}
T\left(s_{A}^{h}, s_{B}\right)-T\left(s_{A}^{l}, s_{B}\right) \geq & \left(q\left(s_{A}^{l}, s_{B}\right)-q\left(s_{A}^{h}, s_{B}\right)\right) V_{A}^{b}\left(s_{A}^{h}, s_{B}\right)+ \\
& \left(q\left(s_{A}^{h}, s_{B}\right)-q\left(s_{A}^{l}, s_{B}\right)\right) V_{A}^{a}\left(s_{A}^{h}, s_{B}\right) .
\end{aligned}
$$

The IC for $A$ 's information $s_{A}=s_{A}^{l}<s^{*}$ is:

$$
\begin{aligned}
& q\left(s_{A}^{l}, s_{B}\right) V_{A}^{b}\left(s_{A}^{l}, s_{B}\right)+\left(1-q\left(s_{A}^{l}, s_{B}\right)\right) V_{A}^{a}\left(s_{A}^{l}, s_{B}\right)+T\left(s_{A}^{l}, s_{B}\right) \\
\geq & q\left(s_{A}^{h}, s_{B}\right) V_{A}^{b}\left(s_{A}^{l}, s_{B}\right)+\left(1-q\left(s_{A}^{h}, s_{B}\right)\right) V_{A}^{a}\left(s_{A}^{l}, s_{B}\right)+T\left(s_{A}^{h}, s_{B}\right),
\end{aligned}
$$

that is,

$$
\begin{aligned}
& \left(q\left(s_{A}^{l}, s_{B}\right)-q\left(s_{A}^{h}, s_{B}\right)\right) V_{A}^{b}\left(s_{A}^{l}, s_{B}\right)+\left(q\left(s_{A}^{h}, s_{B}\right)-q\left(s_{A}^{l}, s_{B}\right)\right) V_{A}^{a}\left(s_{A}^{l}, s_{B}\right) \\
\geq & T\left(s_{A}^{h}, s_{B}\right)-T\left(s_{A}^{l}, s_{B}\right) .
\end{aligned}
$$

The IC conditions (1) and (2) imply

$$
\begin{aligned}
& \left(q\left(s_{A}^{l}, s_{B}\right)-q\left(s_{A}^{h}, s_{B}\right)\right) V_{A}^{b}\left(s_{A}^{l}, s_{B}\right)+\left(q\left(s_{A}^{h}, s_{B}\right)-q\left(s_{A}^{l}, s_{B}\right)\right) V_{A}^{a}\left(s_{A}^{l}, s_{B}\right) \\
\geq & \left(q\left(s_{A}^{l}, s_{B}\right)-q\left(s_{A}^{h}, s_{B}\right)\right) V_{A}^{b}\left(s_{A}^{h}, s_{B}\right)+\left(q\left(s_{A}^{h}, s_{B}\right)-q\left(s_{A}^{l}, s_{B}\right)\right) V_{A}^{a}\left(s_{A}^{h}, s_{B}\right),
\end{aligned}
$$


or,

$$
\begin{aligned}
& \left(q\left(s_{A}^{h}, s_{B}\right)-q\left(s_{A}^{l}, s_{B}\right)\right)\left(V_{A}^{a}\left(s_{A}^{h}, s_{B}\right)-V_{A}^{a}\left(s_{A}^{l}, s_{B}\right)\right) \\
\leq & \left(q\left(s_{A}^{h}, s_{B}\right)-q\left(s_{A}^{l}, s_{B}\right)\right)\left(V_{A}^{b}\left(s_{A}^{h}, s_{B}\right)-V_{A}^{b}\left(s_{A}^{l}, s_{B}\right)\right) .
\end{aligned}
$$

According to (A-2.1), $V_{A}^{a}\left(s_{A}^{h}, s_{B}\right)-V_{A}^{a}\left(s_{A}^{l}, s_{B}\right)>V_{A}^{b}\left(s_{A}^{h}, s_{B}\right)-V_{A}^{b}\left(s_{A}^{l}, s_{B}\right)>0$. Thus, the incentive compatibility implies $q\left(s_{A}^{h}, s_{B}\right) \leq q\left(s_{A}^{l}, s_{B}\right)$, i.e., $q\left(s_{A}^{l}, s_{B}\right)$ should not increase in $s_{A}$.

However, by (A-1), for any given $s_{B}$ when $s_{A}$ increases from $s_{A}<s_{B}$ to $s_{A}>s_{B}$, for any $q\left(s_{A}, s_{B}\right)=\bar{q}$, where $\bar{q} \in[0,1)$ is a constant, the efficiency can be improved by increasing $\bar{q}$, i.e. by $\bar{q}+\varepsilon$, where $\varepsilon>0$. Thus, the efficiency requires $q\left(s_{A}, s_{B}\right)$ to be non-decreasing in $s_{A}$.

Therefore, the only possible scheme of $q\left(s_{A}, s_{B}\right)$ which may satisfy both IC and the efficiency requirement is to keep $q\left(s_{A}, s_{B}\right)$ constant, i.e. $q\left(s_{A}, s_{B}\right)=\bar{q}$. It is obvious that for any $\bar{q} \in[0,1]$, reorganization based on any $\bar{q} \neq q=\operatorname{Pr}\left(s_{A}>s_{B}\right)$ is worse than $q$. However, by (A-1.2), a reorganization decision based on $q$ is worse than liquidation.

The case of bank $B$ can be proved by symmetry.

Given the above results, any randomization between liquidation and reorganization at date 2 will be worse than liquidation. Thus, the probability of liquidation is $1-p=1$. 